\title{
Exploring Professional Development Needs and Strategies for Instructors/Faculty Facilitating ePortfolios Online
}

\author{
Debra Hoven ${ }^{* 1}$ \\ Pamela Walsh ${ }^{2}$ \\ Rima Al-Tawil ${ }^{3}$ \\ Rita Zuba Prokopetz ${ }^{4}$ \\ ${ }^{1}$ Athabasca University \\ ${ }^{2}$ Athabasca University \\ ${ }^{3}$ Athabasca University \\ ${ }^{4}$ Athabasca University
}

\begin{abstract}
This qualitative study sampled 30 university websites across Canada to identify which Canadian universities offer ePortfolio activities to students and faculty members. The researchers from Athabasca University identified eight institutions as offering ePortfolio activities and aimed to explore how faculty or instructors of such ePortfolio activities were selected and what professional development (PD) opportunities were available to them. The study included 11 participants from the eight Canadian universities identified during our search of university websites mentioning ePortfolios. Through a descriptive and interpretive process in a series of 60-90-minute interviews with faculty, educational developers, and instructional designers at the identified universities, the four researchers explored the type of professional development offered to faculty members who are involved or will be involved in ePortfolio use and program integration. The main focus of their interviews was on 1) the nature and type of development offered; 2) how it has been organized; 3) to what extent it has been effective; 4) how faculty members are chosen to teach ePortfolio courses; 5) what lessons have been learned about these factors; and 6) what recommendations are offered or proposed by PD developers, facilitators, and faculty participants. Given that the use of ePortfolios is a rapidly emerging pedagogy in higher education, it is not surprising, perhaps, that faculty development has not kept pace with the practice of ePortfolio introduction. Preliminary results have revealed variations of ePortfolio use (or lack thereof) in higher education. The findings have also revealed the need for a Canadian ePortfolio community to enable practitioners, proponents, and researchers to build on each other's knowledge, share experiences, and engage in the dissemination of open education resources housed in ePortfolio projects.
\end{abstract}

\section{Introduction}

As the only English speaking fully online university in Canada, Athabasca University (AU) offered one of the country's first capstone ePortfolios in a graduate program. In keeping with the university's Strategic Vision and Learning Framework, a working group initiated by the Faculty of Graduate Studies at AU is pursuing campus-wide interest in ePortfolio implementation within graduate programs. In line with these initiatives, it is critical for the 
university community at $\mathrm{AU}$ to understand what skills and characteristics an effective instructor of ePortfolio activities needs, and how they can be developed. Currently, AU does not provide ePortfolio professional development activities for faculty members, instructors of ePortfolios or support staff, yet the literature recommends that this broad approach to PD is essential for effective teaching of ePortfolios and for the success of students in their transition to the workplace and their development as lifelong learners (Carpenter et al., 2017; Costelloe, 2021; Eynon \& Gambino, 2016; Hoven, 2020; McNair et al. 2012; Penny Light et al., 2012). Having identified these skills and characteristics in this research study, we anticipate dissemination of this information within and beyond the university, to better prepare faculty and staff elsewhere in their facilitation of ePortfolio implementation.

\section{Context}

The potential and real impact of ePortfolios is well documented in the literature (Eynon et al, 2014; Harring \& Luo, 2016; Watson et al, 2016; Scully et al., 2018). Furthermore, Watson et al. (2016, p. 66) argued that essential to the success of ePortfolio implementation "is the ability to embrace and devote resources to the ePortfolio as an engaging pedagogy" across colleges and universities. ePortfolios take a reflective pedagogical approach and may change the way faculty and students perceive the teaching and learning process. However, there are very few studies that address the importance of PD for faculty members in ePortfolio use in teaching and learning, and this scarcity in the scholarly literature is especially true in Canada. Our research project aimed to help address this gap. In addition, since websites are now taking the place of course textbooks, ePortfolio sites - highlighting collections of artefacts from faculty and students - are rich in data; as such, they may serve as open educational resources where creators (faculty, students, researchers, curators) have an opportunity to coconstruct knowledge and contribute more widely to the field of online, open, digital, and blended learning.

This exploratory interpretive research study on PD needs for faculty is significant in many aspects. The purpose was to gain insights into the experiences of faculty or instructors involved in ePortfolio activities at the Canadian institutions identified as offering ePortfolio activities. Our research team of four, therefore, set out to learn about how faculty or instructors are selected and what PD opportunities are available to them.

\subsection{Addressing the Literature Gap}

As mentioned above, there are gaps in the literature about the nature and role of faculty development relating to ePortfolio pedagogy and roles and good practices in higher education, both worldwide and more specifically in Canada. As evidenced by research, ePortfolio integration has great potential to play a transformative role in higher education. The Association of American Colleges and Universities (AAC\&U), for example, has identified ePortfolios as the eleventh High Impact Practice (HIP) in student success - both academically and professionally (Watson et al., 2016). Findings of research in the past decade have documented that high-impact practices help students engage in deep approaches to learning (Kuh, 2008); students who use these approaches tend to earn higher grades and retain, integrate, and apply information at greater rates (Watson et al., 2016). ePortfolios represent non-traditional means to credential learning, have the potential to personalize and 
transform students' learning experiences, and correlate with student success - including employability (Eynon et. al, 2014; Hoven 2014, 2020).

As demonstrated by our interviews with the 11 study participants, the various themes that emerged surpassed the data required to address the research questions. Participant responses uncovered aspects of technology (choice of platform), pedagogy (need to make it open and organic), interaction (engagement of community members), and reflection (sharing of lessons learned) as well as a need for ePortfolio PD experiences (see Figure 1). Albeit relevant and worth pursuing in a future study, some of the emerging themes were not included in the data coding and analysis; a decision made by the research team in order to complete this study in a reasonable timeframe.

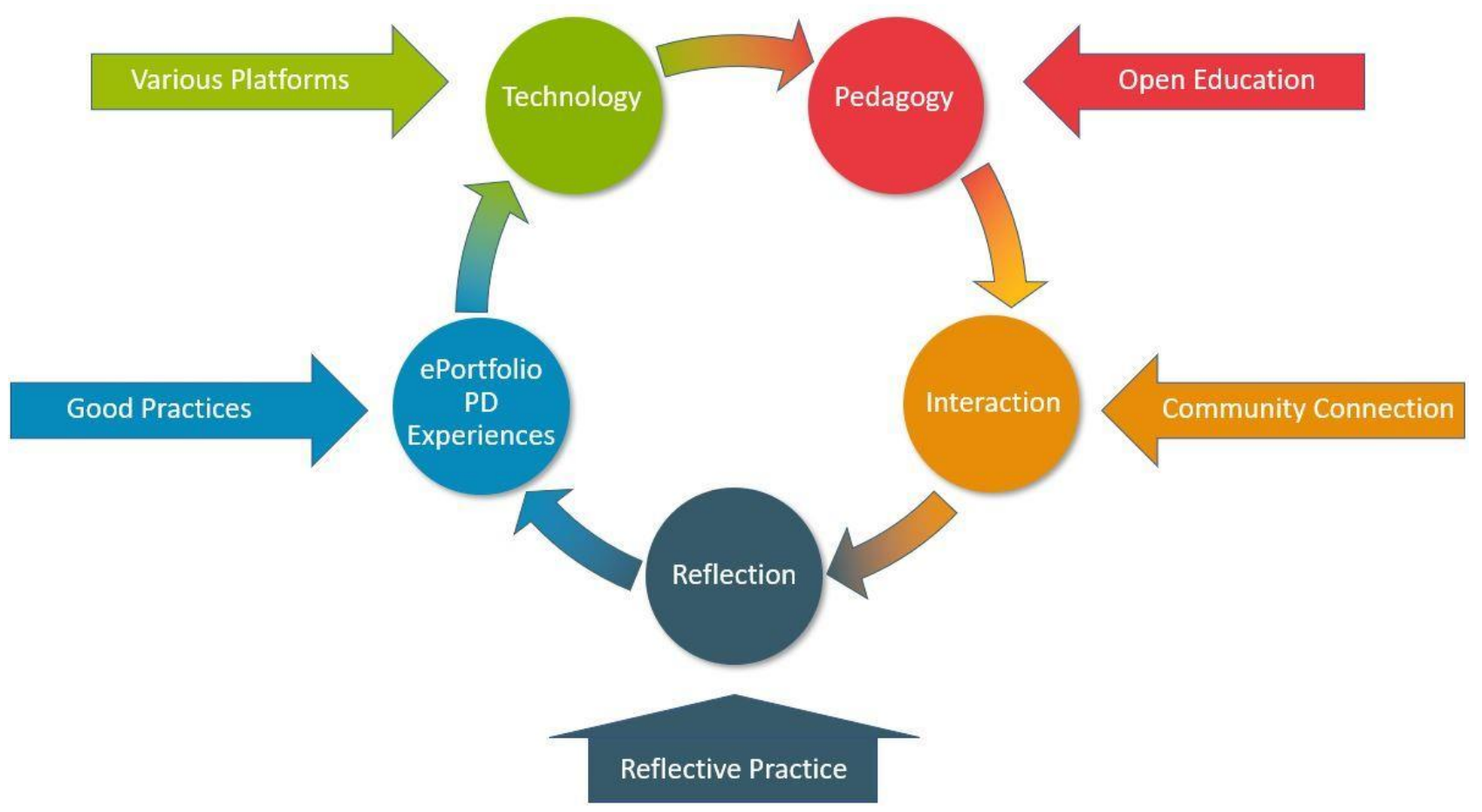

Figure 1: The need for further studies

Adapted from Zuba Prokopetz (2020a, 2020b)

\section{3. ePortfolio Landscape}

ePortfolios have been offered at educational institutions at various levels around the globe since the technology began being used in education (Danielson \& Abrutyn, 1997). The educational or learning portfolio idea, adopted in writing and composition in the 1980s, first gained prominence in the education field in mid 1990s in a paper-based format (Batson, 2015, 2018; Cambridge, 2010; Danielson \& Abrutyn, 1997; Eynon \& Gambino, 2017; Farrell, 2020; Ravet, 2005). Since then, the educational portfolio has evolved into electronic formats with a "surprising variety of uses academics are discovering for portfolio 
technology" on campuses around the world (Batson, 2010, para.1). ePortfolios became more prominent in North American colleges and universities after the analysis from the 2003 Campus Computing Project Survey showed that the time had arrived for educators to consider ePortfolios as more than just an interesting classroom innovation, and for scholars to recognize the need for research to catch up with practice (Cambridge, 2009). The survey resulted in the formation of the Inter/National Coalition for Electronic Portfolio Research (INCEPR) in 2003. While many Canadian universities appear to be promoting ePortfolio use in the classroom, the availability of faculty development opportunities is, at best, unclear. Furthermore, there appears to be less information and research on professional development for faculty who teach or facilitate graduate courses that utilize ePortfolio pedagogy and reflective practice. This study aimed to address that research gap.

A recent study funded by the National Forum of Teaching and Learning in Higher Education in Ireland explored the potential of digital teaching portfolios to support various forms of professional development in higher education (Costelloe, 2021). Study participants from the three participating institutions welcomed "the affordances of ePortfolios to support engagement in professional learning activities in order to enhance academic practice" (Abstract). Some of the participants, however, perceived the ePortfolio-creation praxis as time consuming - an endeavour that necessitated some form of support. Among the challenges with ePortfolios, as suggested by Barrett (2004, para. 1), is maintaining "learner intrinsic motivation to willingly engage in the portfolio process." This assertion holds true for all types of learners - faculty, administration, students.

In this context, Ring et al. (2016) examined a faculty development structure that seemed sustainable and could support ePortfolio usage. The authors focused specifically on identifying the characteristics of engaged faculty and identifying best practices to facilitate their professional development. Based upon the findings, Ring et al. concluded that an appropriate faculty development system can increase faculty support and buy-in and potentially transform teaching and learning - thereby benefiting students in both their professional and academic lives. In their study across 30 courses, Tse et al. (2018) highlighted benefits to students when instructors have a more intentional perspective toward ePortfolios. Data from their mixed-methods study with more than 800 students revealed that students usually benefit most when instructors are invested in the course. In order for instructors to appreciate and feel more connected with the ePortfolio pedagogy, they would require guidance and mentorship before and during their initial facilitation of an ePortfolio course. In this way, they would be able to show "a long-term investment in the course ... [by] teaching it more than one time" and also "taking a hands-on approach with the administration of the eportfolio" (Tse, 2018, Abstract).

\subsection{Evolving Support and Practices}

Within the last two decades or more, ePortfolio or Learning Portfolio practice has been evolving in many parts of the world, and, in consequence, so have communities of professional practice. In North America, ePortfolio practice has played a long-standing role in post-secondary education. In Canada, ePortfolios are more commonly implemented in universities, whereas in the United States, ePortfolio practice has gained ground more within the college system with their greater focus on service learning and transition to the workplace. In the United States, for example, ePortfolio proponents, practitioners, and researchers rely on organizations and resources like the American Colleges and Universities 
(AAC\&U), the Association for Authentic, Experiential and Evidence-Based Learning (AAEEBL), the International Journal of ePortfolio (IJeP), and the Electronic Portfolio Action and Communication (EPAC) Community of Practice for professional and academic support. In addition, the AAEEBL ePortfolio Review (AePR) magazine offers support to emerging researchers as they begin publishing their first articles on their experiences. In terms of open resources (for all types of instruction, including ePortfolio pedagogy) and guidance on course redesign, the Multimedia Educational Resources for Learning and Online Teaching (MERLOT) shares ongoing updates of its robust repository built and maintained with the assistance of community members.

In Canada, several universities have adopted ePortfolios and many have produced presentations and papers in the area of Scholarship of Teaching and Learning (SoTL), exploring variously learning support (Wade et al., 2005), learner engagement and challenges (Tosh et al., 2005), ePortfolios and self-regulated learning (Abrami et al., 2008), and more recently, ePortfolios as a HIP (Vaughan et al., 2017). There is shared knowledge among professionals in these educational institutions; however, there appears to be a need for a community where, as posited by Wenger (1998), there is mutual engagement of participants, and "negotiation of meaning" as understood by the concept of practice (p.72). This concept of community will be explored further in our findings and recommendations, as there seems to be a broad-based need emerging, for both ePortfolio facilitators and students.

Europortfolio, a community that aims to explore European practice and research, has chapters in Austria, Croatia, various francophone countries, Germany, the Nordic region, Poland, Spain, Switzerland, and the United Kingdom (UK). The UK chapter was launched in 2014 to focus on emerging opportunities and challenges (Europortfolio, n.d.). The European Language Portfolio (ELP) project underwent years of scholarly research and discussion before its pilot during 1998-2000 and subsequent establishment as a recognized professional body in 2001 (Zuba Prokopetz, 2013). Relying on the two Continuing Professional Development frameworks of the British Council, the members of the Council continue to address the needs of teachers, teacher educators, and newly qualified teachers working with English language teaching (British Council, n.d.).

The Irish ePortfolio community is growing in terms of members and activities. In 2019, there was a nationwide survey of ePortfolio practice to gain a view of the landscape applications and technologies in Irish higher education (Farrell, 2019). Since then, Eportfolio Ireland has provided its members with educational webinars and opportunities for publication.

In Australia, the ePortfolio community has been gathering momentum since 2010 with the follow-up work drawing from a national survey conducted three years earlier (Cambridge, 2012). The community includes the ePortfolios Australia website - a professional network that supports members through professional development and resources and a Facebook community of practice.

\subsection{Athabasca University Context}

As mentioned earlier, there is a growing interest in using ePortfolios in teaching and learning across Athabasca University. Innovative and transformative teaching and learning is referenced in the Imagine plan's strategic direction: "Moving beyond the norm, ... adopting innovative ideas and taking calculated risks" (Athabasca University, 2018, p.4). ePortfolio 
integration in teaching and learning practices is consistent with the key themes of Imagine including "Disruptive pedagogies." As the only English speaking fully online university in Canada, Athabasca offered one of the country's first capstone ePortfolios in a graduate program. The capstone ePortfolio course, accredited in 2015, is the final course in the Master of Education (MEd) program. It is a program-centric project that enables students to explore and demonstrate the development of the core competencies developed over the whole program (Hoven, 2014). Hoven, the designer and one of the core instructors of the ePortfolio course in the MEd, states that ePortfolios in the graduate programs have a partial assessment aspect. She further explains that the student artefacts, accompanied by reflections, are shared with the course instructor and peers. This meaningful process, she adds, enables students to demonstrate and discuss what they have learned and the competencies they have attained during the program of studies, bringing their learning into the conscious realm (Hoven, 2020).

\subsection{Disruptive Pedagogy and Reflective Practice}

ePortfolios are being considered an innovative and disruptive pedagogy because they include non-traditional means to credential learning, have the potential to personalize and transform students' learning experiences, and correlate with student success (Eynon et. al, 2014). They take a reflective approach to pedagogy and have the potential to change the way faculty and students perceive the teaching and learning process (Hoven, 2020). Several Canadian universities have made reflective practice and ePortfolios a part of the requirements for obtaining an education and other degrees. Some now have programs that use ePortfolios to assess the aggregated work of their students and the ePortfolio project presentations were introduced as an alternative to the comprehensive exams previously used to assess graduate students (Conrad \& Openo, 2018). The MEd program at Athabasca University, for example, requires students who pursue the course-based route to develop and present their ePortfolios as a final capstone project (Hoven, 2014, 2020). In the nursing profession, ePortfolios have become prominent, and are being used regularly by student nurses and nurse practitioners. These ePortfolios provide nurses, students and professionals, a place to record their professional growth over time not only for themselves, but also for their employers, and peers; they deepen learning and further interest in professional development (Green et al., 2014). However, while higher education institutions recognize the importance of reflective practice, it remains unclear how faculty apply the process of reflection in their own teaching (Giaimo-Ballard \& Hyatt, 2012).

\subsection{A Need for Professional Development}

If high impact practices represented by ePortfolio integration are to be adopted across higher education institutions, faculty members need professional development to support them in this innovative integration. This suggests that "Institutions need to be intentional in the design, implementation, and scaling" of high impact practices (McNair \& Albertine, 2012) such as ePortfolios. Watson et al. (2016) support Eynon \& Gambino's (2017) assertions that professional development initiatives among faculty and other staff are important to successful implementation. Under the umbrella of the Connect to Learning Project (C2L) which comprised 24 colleges and universities across the United States, Eynon et al., (2014) had earlier documented the work and findings of ePortfolio teams. The research undertaken in the $\mathrm{C} 2 \mathrm{~L}$ project suggested that "effective ePortfolio initiatives build vibrant programs in five interlocking sectors", and among these sectors is professional development in the form of 
workshops, institutes, and seminars that help faculty and staff gain better understanding of pedagogy and technology. Eynon et al. noted that $\mathrm{C} 2 \mathrm{~L}$ findings also emphasized that "faculty development was instrumental to ensuring the quality of ePortfolio practice and to helping faculty explore, test, and adapt integrative, social ePortfolio pedagogy for the needs of their disciplines and courses" (p. 105). Further, findings of a study by Marshall et al. (2017) revealed that a two-day ePortfolio Assessment Institute increased faculty members' confidence in teaching and assessing outcomes related to ePortfolios. The authors concluded that faculty confidence can be increased by structuring assessment activities as opportunities for faculty learning.

\subsection{A Need for Good Practices}

Eynon and Gambino (2016, 2017) and the European report of Scully et al. (2018) argued that if done well, ePortfolio-based professional development has the potential to support transformative student learning across the institution, and that such professional development is a critical component in reflective ePortfolio pedagogy. Without the inclusion of effective professional development strategies, high-impact ePortfolio practice will not gain traction in higher education. The availability of a comprehensive good practice handbook for ePortfolio pedagogy in higher education has not been readily available (Eynon \& Gambino, 2016; Eynon et. al, 2014), particularly in Canada. Discussions with ePortfolio instructors indicate that faculty members may find it difficult to make the connection visible and understandable for students between ePortfolio assignments and overall course goals (Harring \& Luo, 2016). A 2017 Canadian study at the University of Waterloo looked at learner and instructor approaches and reactions to ePortfolio usage (Scholz et al., 2017). The authors found that the role of the instructor is critical to ensuring successful ePortfolio implementation and recommended that "well-thought-out, intentional ePortfolio task designs" be considered by instructors who are invested in the successful use of ePortfolios by students (p. 149). Also critical in ePortfolio implementation is the role students play in the overall success. An American career-focused teaching institution with campuses in five states in the U.S. considered transitioning to ePortfolios after a decade of portfolio use in their undergraduate programs; the institution had prior experience using these portfolios for student professional development (Penny Light et al., 2012). As part of student preparation for ePortfolio use at this educational institution, there was a mandatory seminar on portfolio development before students were able to submit their project for review. Professional development for students could be another area for future research, since understanding ePortfolio use is equally important for all stakeholders involved. As noted by a Canadian non-profit corporation, as institutions, faculty, and students worldwide gradually attempt to adjust to a new kind of post-pandemic normal, their ability to respond to change will either enhance their opportunities or deem their complacency unsustainable (Contact North, 2020).

\section{Methodological Approach}

This exploratory interpretive research study enabled the research team members to gain insights into the experiences of 11 educators involved in ePortfolio activities in the eight universities identified in the initial web search as using ePortfolios. As illustrated in Figure 2 below, we took a reflective, dialogic process in our implementation of the various stages and components of our qualitative research cycle, beginning with research ethics approval from our university. Themes and next steps emerged organically as we regularly met and discussed 
our insights and reflected collectively on what each emergent set of findings meant to us as individuals, as sub-sets of the team, and the team as a whole. The fact that each of us brought our own unique skills and experiences to the dialogue greatly enriched the insights gained and expressed in our discussions.

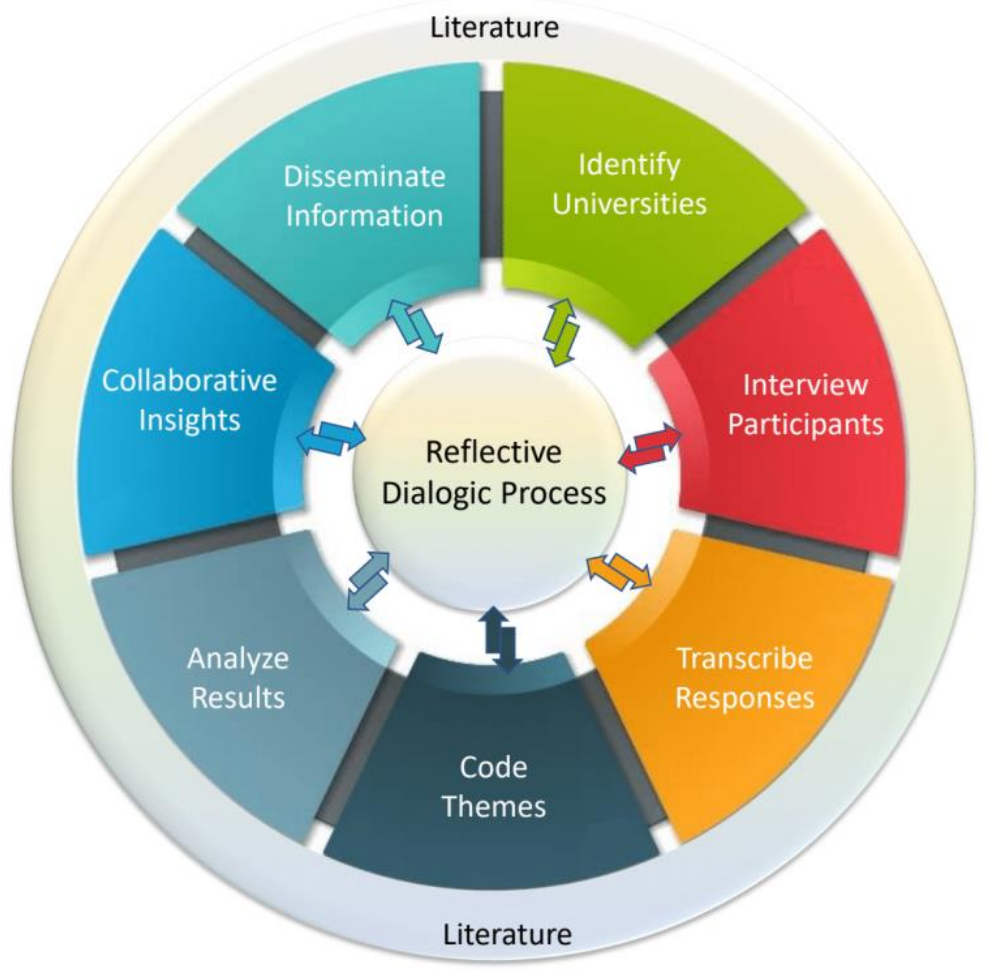

Figure 2: Our research cycle

\subsection{Universities and Participants}

Using convenience sampling, we checked the websites of 30 universities across Canada. While our aim was to include participants from at least one university in each of the 10 Canadian provinces, we were only able to purposefully select universities from seven provinces, based upon website evidence of ePortfolio practice within courses or programs. Institution size ranged from small to large. Our selection criteria for participants included experience in organizing, delivering, or participating in portfolio activities or related training activities within their universities. Using the information provided on the websites, our knowledge of ePortfolio practitioners, and referrals by colleagues and participants, we were able to contact prospective interviewees by email. We interviewed 11 participants in universities located in seven Canadian provinces. Participants comprised both faculty members and educational developers or designers.

\subsection{Research Questions}

For the purposes of this study, in order to broadly explore professional development opportunities and activities, as well as how instructors are selected or self-select to facilitate integration of ePortfolios, we developed the following research questions: 
1) What professional development activities are available for university faculty for ePortfolio practice in courses and projects across a selection of Canadian universities; how were these activities chosen and developed; what activities are perceived to be effective; and what lessons have been learned from PD opportunities?

2) What skills or characteristics are deemed to be important for faculty effectiveness in ePortfolio activities? What recommendations are offered or proposed?

These questions formed the two layers of the study. The first layer (Layer A) raised questions aligned with professional development activities across a selection of Canadian universities. The second layer (Layer B) explored the skills or characteristics viewed by participants as a requirement for faculty involved in ePortfolio activities. Responses to these questions were explored through audio-video interviews using Zoom, in keeping with the data collection techniques of an interpretive research study. All indicators and data available before our study seemed to show that, while higher education institutions recognize the importance of reflective practice, there seems to be a general lack of clarity around how faculty apply the process of reflection in their own teaching (Giaimo-Ballard \& Hyatt, 2012). If high impact practices represented by ePortfolio integration are to be adopted across all levels of higher education, faculty members need professional development for pedagogical innovation (McNair \& Albertine, 2012) as well as increased awareness of the role and value of critical reflection in both teaching and learning.

\subsection{Data Collection and Analysis}

As a team, we conducted and recorded the 10 semi-structured interviews with 11 individuals (two participants were interviewed together at their request) using Zoom technology. We shared a summary of the questions with participants two to four days in advance. These questions were informed by the literature and our own experiences as ePortfolio practitioners. At the start of each interview, we affirmed our commitment to preserving confidentiality and anonymity of our participants and their universities in accordance with the research ethics approval gained from our university. The interviews averaged 1.5 hours in duration. Transcripts were reviewed and validated by participants, and any changes were incorporated by a member of our team. This was followed by de-identification before data analysis.

We used an inductive coding process and two of our team members coded the data collaboratively, both manually and electronically using NVivo 12 Plus software, with one other member coding manually. All coding was then pooled and discussed. We used Miro ${ }^{1}$, an online white board, which allowed us to work collaboratively as we organized and conceptualized the data.

\section{Findings and Participant Recommendations}

The first of two aims of this study was the portrayal of the stories and experiences of faculty members/instructors, educational developers and instructional designers who have been involved in participation, organizing or providing professional development opportunities. As depicted in Appendix 1 (Layer A), visualization of data in a Miro board facilitated the broad

\footnotetext{
${ }^{1}$ Miro boards are digital whiteboards used to visualize themes and collaborate with others
} 
headings under which PD activities were grouped, and these are: activities available (or lack thereof), examples, and effectiveness.

\subsection{Professional Development (Layer A: Appendix 1)}

As the interviews revealed, most participants indicated that they had not received any formal PD that prepared them for using ePortfolios. To describe how they prepared themselves, a few participants discussed joining conferences or workshops with PD opportunities in ePortfolios, while others mentioned adopting a self-directed approach, sometimes learning alongside the students. This "self-training", as some participants referred to it, included reading relevant literature, exploring online resources, experimenting with the platform, and networking with colleagues. In this regard, a faculty member remarked:

Your question around professional development, I don't know, I'm just making it up as I'm going along. Honest to God, like, I'll listen to podcasts, I'll do whatever, I have no problem saying, "Hey, I don't know what I'm doing here. I'm stuck on this point; can you help me think through this?" I have a strong professional learning network that I've built where I've got lots of friends who if I call them up, they'll talk through it with me. The internet's great. (M5)

Having one-on-one sessions with instructors interested in ePortfolios emerged as one of the major themes pertinent to the question around PD activities, particularly in universities with centres for teaching and learning. Participants working in such universities commented that specialized staff (e.g., instructional designers, educational technologist and/or developers) usually have conversations with the faculty member around what they want to achieve from the ePortfolio and how to design it into their course.

Several participants discussed opportunities for faculty to attend conferences and workshops with integrated ePortfolio PD activities. Although such events may not necessarily be about ePortfolios per se, they often contain components related to ePortfolio pedagogy, such as student assessment and the art of providing feedback. Drawing distinctions between the pedagogical and technological aspects of ePortfolios, one participant remarked that PD activities dedicated for using ePortfolios are "usually technology-based ... here's the ins and outs of the tool" (M5). Along the same line, another participant highlighted that at their university, "it's strictly the [platform] workshop which supports a lot of people who are thinking about going towards ePortfolios, but it's not specific to ePortfolios". (Q2-4)

Commenting on the effectiveness of the PD workshops, an experienced educator argued that:

No matter how lengthy or intensive a one-day or multi-day workshop is, it is merely the starting point. Faculty only really have questions when they start implementing, and you must be there to support them through the entire process. (J3)

From these responses, it seems that PD activities need to aim at both pedagogical and technological educational development. Instructors need to see the pedagogical value of incorporating ePortfolio pedagogy as well as be educated about how to become comfortable 
using the technological platforms supported by their universities. Furthermore, professional development needs to take the form of staged or phased activities that continue to support instructors as their skills, familiarity, and buy-in progress.

\subsection{Characteristics (Layer B: Appendix 2)}

The second aim of our study was to elicit from participants their perceptions and experiencebased understandings of what characteristics are useful or necessary for instructors to successfully facilitate integration of ePortfolios. Pedagogical knowledge and skills and the ability to facilitate learner agency were among the most notable themes identified in the responses of participants. One experienced facilitator of student learning and ePortfolios emphasized the importance of pedagogy and theoretical constructs in ePortfolio implementation by instructors and faculty members:

[They] have to value the integration of portfolios, the process of self-regulation, and the socio-constructivist approach that underlies process portfolios (J3).

Relying on the words of King (1993), the same participant further suggested that educators have to understand that they are "not the sage but the guide on the side". Similarly, other participants voiced the importance of not only empowering students to be in charge of their own learning but also allowing them to demonstrate that learning. Others suggested that valuing a student-centered approach includes helping students to meet their learning objectives and addressing the struggles inherent in creating a process ePortfolio.

In contrast, an educator from a teaching and learning centre argued that, while students enjoy the creative freedom, they may "forget about the pedagogy of the ePortfolio" (B5). This cautionary statement was followed by an acknowledgement of the importance of providing substantive feedback to facilitate student learning and help them stay on track.

A leading educator in ePortfolio practice emphasized the importance of alignment of teaching philosophy with ePortfolio practice and shared the view that faculty members involved in or selected to facilitate ePortfolio courses or projects should be a "reflective, integrative kind of thinker" (D2).

Many participants discussed the value of encouraging and inspiring students while guiding them through the reflective process.

You need a sort of a guide, a coach, an individual that is willing to slow down the thinking because so many times... students will want to race to the end, and race through the portfolio process; race through the reflections. (H8-1)

While discussing their views about faculty characteristics for ePortfolio facilitation, several participants reflected on the importance of self-selection, and of working with faculty who are inquisitive and genuinely interested in learning something. Many emphasized the importance of faculty patience, motivation, and willingness to invest the time in setting themselves and students up for success. As one instructor explained:

You put your heart into what you do, but then you know that it's a marathon.... and it's through your repetition of the same process over and over that you will get 
somewhere. I had to force myself to do the same assignments that I was asking the students; to go through the thinking process that I want the students to do. (F3)

Several participants shared their own vulnerability and the "emotional time and emotional effort it takes to try things" that may not go well the first time (F3). A recurrent theme was willingness to take risk. One faculty member revealed that she is an explorer, while others spoke about risk-taking as an essential or ideal characteristic.

If I think a fire is going to cultivate conditions for better learning, I'll run into that fire... I have no problem being vulnerable in this space.... I'm learning as I go and students are allowing me to learn with them. (M5)

In addition to discussing PD experiences and instructor characteristics essential or desirable for effective ePortfolio facilitation, participants also offered a range of recommendations on how to move forward, as well as passing on comments on lessons they have learned during their implementation of ePortfolios.

\subsection{Participant Recommendations and Lessons Learned}

While some lessons participants learned from their experiences and their recommendations for on-going development and improving ePortfolio practice overlap with findings reported under Layers A and B, others transcend these layers. Observations in response to our interview questions around "lessons learned" were broadly grouped, using insights from NVivo coding, into three categories, as follows:

1. Location of ePortfolios in the university curriculum structure

2. Introducing and supporting ePortfolio practice

3. Structuring on-going development and support

In relation to the first category, participants were adamant that ePortfolio practice needs to be designed into a university-wide or campus-wide initiative, integrated across the curriculum, across programs and across courses. As one participant commented:

I think that it becomes really powerful, actually, when it is integrated across the university, and not rooted in different silos. (D2)

$\ldots$ and another suggested:

My overarching lesson learned, as far as ePortfolio activities, is to try to get into it at the program design stage. Try to design portfolios at that curriculum-wide program stage. (Q2-4).

The second category above included suggestions and recommendations about when, where, and how faculty can and should engage in their own ePortfolio practice. Some of these suggestions included recommendations for PD timing and activities, from both faculty and educational advisor perspectives. Several participants strongly advised faculty to develop their own ePortfolios, both to become familiar with the technology and to mimic the student experience. As one instructor shared:

I would have appreciated somebody just telling me maybe at the very beginning, it would be a really good idea if you became very familiar with [the technology] and 
produced your own portfolio or an outline one or one or two, you know, bits before you start teaching. (C8)

Similarly, an education developer said:

I think the best PD activity is... take the faculty member through this exact same activity you would take a student through. (E4)

...while another emphasized:

Working diligently alongside instructors, meeting them where they're at, and over the years, being able to say, "I don't think this is the time for you. I don't think this is a good use of your time. If you're not going to put the work into it, I don't think you should be using it." (P6)

... ultimately to ensure success, this professor emphasized:

Number one, the teachers, the faculty need to expect that if they introduce a portfolio into their teaching, they believe that they will be successful; so, whatever professional development you do, it has to create in them, "Yes, I can do this". (J3)

Finally, the third category of recommendations reflected the need to provide on-going development and support, not just a one-off workshop or a series of introductory workshops. One participant, for example, recommended building up a cadre of student-peer supporters:

So, these would basically be students who are trained using the [ePortfolio] technology to support other students using the technology. (D2)

Another had found experience with a rotating series of workshops of different kinds, all relating to or supporting ePortfolio pedagogical practices:

.... menu of different items, whether it be the technology, whether it be reflection, whether it be how to craft different artifacts, looking at assessment. So, having all of these smaller pieces that are part of an ePortfolio journey that is offered in a carousel (H8-1).

This latter suggestion, in particular, provides support for offering graduated or staged workshops of different kinds, at different levels, where perhaps more experienced ePortfolio practitioners might also demonstrate and talk through how and why they made certain decisions. This also lends strength to the experience mentioned by a few other participants that for ePortfolio pedagogy to gain traction, there needs to be a team of involved and committed practitioners with a "champion" to push for the harder decisions, sustainable practice, and wider acceptance.

In this context, we are reminded of the literature discussing the efficacy of a community of practice referred to earlier. However, among our participants, both those with years or even decades of experience and relative newcomers to ePortfolio practice, emerged the expressed desire to form or become part of a Community of Support (CoS). They indicated that they are able to locate and access introductory materials and resources through conferences, websites 
or the literature, but that what they feel is still lacking in Canada is a supportive community of ePortfolio practitioners. To such a community they would be able to bring questions, challenges, and examples of "failure to launch" (Farrell, 2018) - to discuss and seek solutions to move forward, improve and make changes in their practice - or just relieve feelings of isolation in their practice.

\section{Conclusion and Looking to the Future}

As we have now come to the end of this stage of our practical analysis, recommendations, and conclusions about the availability and efficacy of ePortfolio professional development opportunities and instructor characteristics necessary for successful ePortfolio design and facilitation, it is time to reflect ourselves on what the main takeaways are so far. We have heard from our participants the need for collaboration on transdisciplinary initiatives, the development of campus-wide design, development, and support teams comprising faculty, administrators, students, and educational technologists. Participants also shared that essential characteristics of good ePortfolio facilitators include risk-taking, experiencing and modelling reflective behaviour for students by creating our own ePortfolios - thereby exposing certain vulnerabilities.

Finally, we have heard overwhelmingly from participants of the need to develop a CoS within Canada, ideally hosted on a website that is accessible across Canadian time zones and spheres of education, with just-in-time or on-demand and recorded live synchronous webinars on a variety of ePortfolio-related topics. We envisage something along the lines of the carousel of related workshop activities suggested by one of our participants, alongside short, pocket-sized expert lectures. This $\mathrm{CoS}$ would need a carefully structured and open interface hosting a combination of $\mathrm{Q}$ and $\mathrm{A}$ discussion, co-creation of a publication list of recent relevant resources, and dissemination of a schedule of upcoming webinars as well as an archive of recordings. This collaborative community would also require funding for hosting, setup and maintenance, as well as outreach to other like-minded communities, not just in North America but also Europe, Australia, New Zealand and elsewhere.

Looking to the future, we anticipate applying for funding to explore student experiences and opinions about how they might develop the reflective capabilities necessary to produce ePortfolios that are meaningful and useful for them, for both the purposes of their programs of study and also beyond graduation to workplace transition and enhancement of their lifelong, life-wide learning skills and practices. As alluded to earlier, this exploratory research process has left us with a sense of awe at the range and potential of ePortfolios for learning in many forms and modalities. Our next endeavour in this trajectory is to expand our dialogic process in which we explore our own reflective and reflexive capabilities and practices in developing our own ePortfolios, past and current, and to dialogically reflect on how better to model our reflexivity for expanding research possibilities. 


\section{Appendix 1}

\section{Visualization of emergent themes for Layer A}

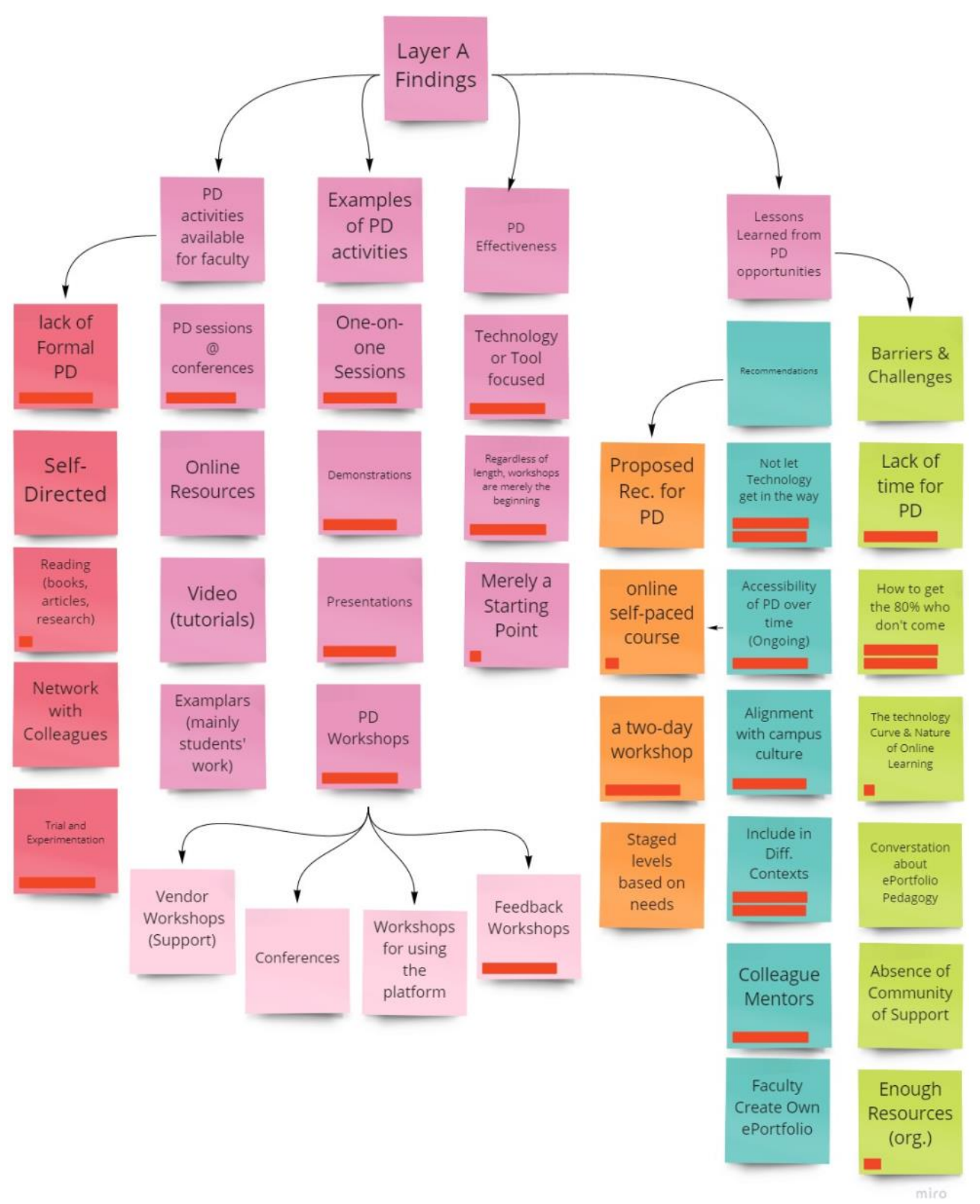




\section{Appendix 2}

\section{Visualization of emergent themes for Layer B}

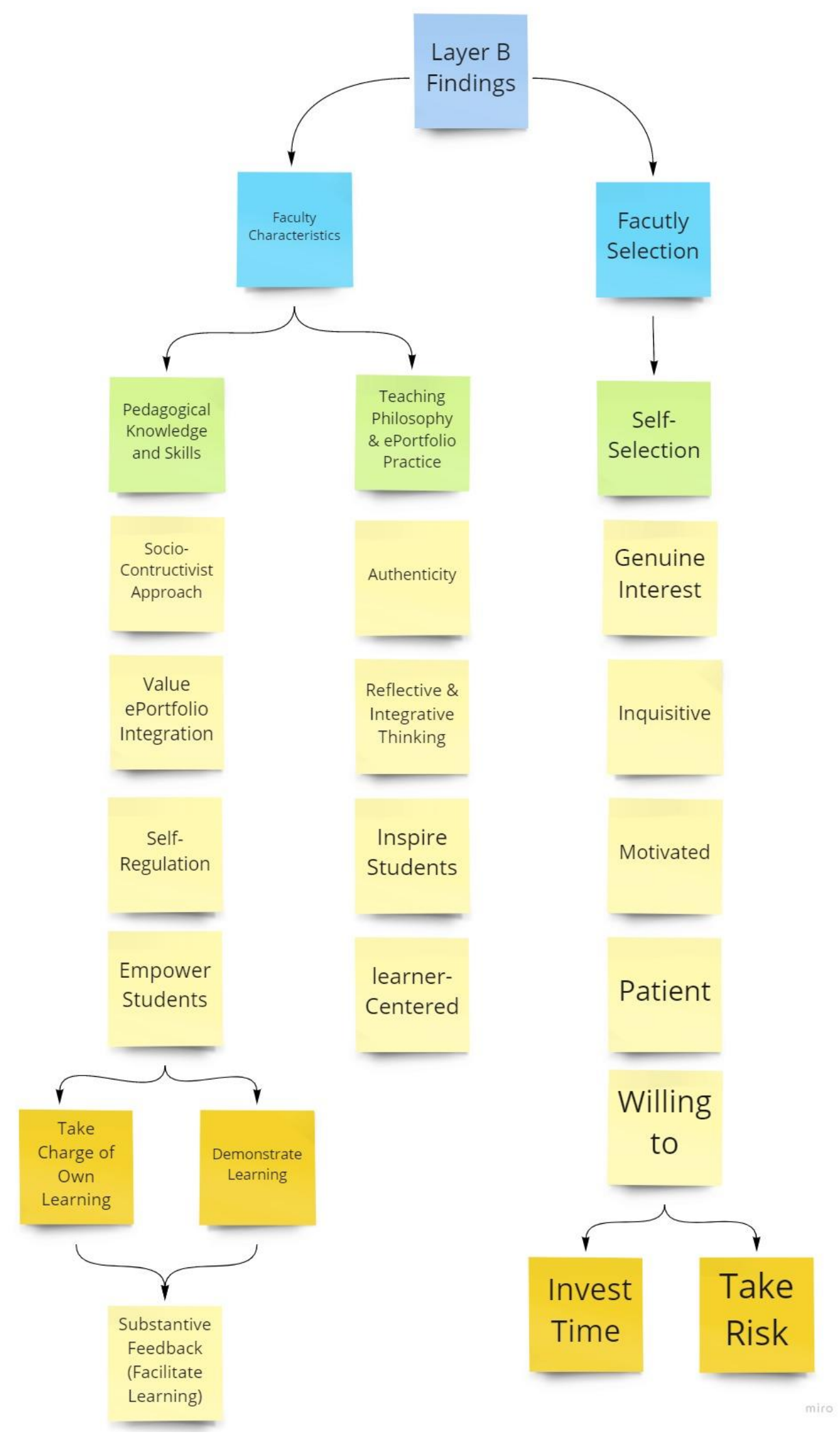




\section{References}

Abrami, P.C., Wade, C.A., Pillay, V., Aslan, O., Bures, E.M., \& Bentley, C. (2008). Encouraging self-regulated learning through electronic portfolio. AU Press, (34)3. http://electronicportfolios.org/academy/intro/resources/reflection-cycle/Encouraging\%20selfregulated $\% 20$ learning $\% 20$ through $\% 20$ electronic $\% 20$ portfolios $\% 20 \% 7 \mathrm{C} \% 20 \mathrm{Abrami} \% 20 \% 7$ C\%20CJLT.pdf

Association of American Colleges and Universities. (2021). 2022 Institute on ePortfolios. https://www.aacu.org/events/2022-institute-eportfolios

Athabasca University (2018). Strategic Research Plan: Athabasca University 5-year strategic plan / 2018 - 2022. https://www.athabascau.ca/research-centre/documents/strategicresearch-plan-2018-2022.pdf

Barrett, H. C. (2004). Electronic portfolios as digital stories of deep learning: Emerging digital tools to support reflection in learner-centered portfolios.

http://electronicportfolios.org/digistory/epstory.html

Batson, T. (2018). The eportfolio idea as guide star for higher education. The AAEEBL ePortfolio Review, 2(2), 9-11.

https://drive.google.com/file/d/0B5EyRIW5aG82dGtQTjJEcVk2R21JazZuRjFyb3BucVBMb UFZ/view

Batson, T. (2015, February 2). Study shows steady growth in eportfolio use: What does that mean? https://drive.google.com/file/d/1ZVXXO2bmCoHXcM1ZYV20ejxiOw8kjJdC/view

Batson, T. (2010). Review of portfolios in higher education: A flowering inquiry and inventiveness in the trenches. Campus technology website.

https://campustechnology.com/articles/2010/12/01/review-of-portfolios-in-highereducation.aspx

British Council (n.d.). Professional development. Teaching English. https://www.teachingenglish.org.uk/professional-development

Cambridge, D. (2012). E-Portfolios and global diffusion; solutions for collaborative education. Information Science Reference. https://doi.org/10.4018/978-1-4666-0143-7

Cambridge, D. (2010). Eportfolios for lifelong learning and assessment. Jossey-Bass.

Cambridge, B. (2009). On transitions: Past and present. In D. Cambridge, B. Cambridge, \& K. Yancey (Eds.), Electronic portfolios 2.0: Emergent research on implementation and impact (pp. xi - xvi). Stylus.

Carpenter, R., Morin, C., Sweet, C., \& Blythe, H. (2017). Editorial: The role of faculty development in teaching and learning through high-impact educational practices. The Journal of Faculty Development, 3(1), 7-12. 
Conrad, D., \& Openo, J. (2018). Assessment strategies for online learning: Engagement and authenticity. Athabasca University Press.

https://www.doi:10.15215/aupress/9781771992329.01

Contact North (2020, October 07). Online learning at a tipping point? TeachOnline.CA. https://teachonline.ca/tools-trends/online-learning-tipping-point

Costelloe, L. (2021). Exploring the potential of digital teaching portfolios to support in/nonformal professional development for those who teach in higher education. Irish Journal of Technology Enhanced Learning, 6(1), 1-13.

https://journal.ilta.ie/index.php/telji/article/view/72/94

Danielson, C., \& Abrutyn, L. (1997). Introduction to using portfolios in the classroom. Association for Supervision and Curriculum Development.

http://www.ascd.org/publications/books/197171/chapters/Introduction.aspx

Europortfolio (n.d.). Chapters. European Network of ePortfolio Experts \& Practitioners. http://www.eportfolio.eu/community/chapters

Eynon, B., \& Gambino, L. M. (2017). High-impact ePortfolio practice: A catalyst for student, faculty, and institutional learning. Stylus.

Eynon, B., \& Gambino, L. M. (2016). Professional development for high-impact ePortfolio practice. Peer Review, 18(3), 4-8. http://www.aacu.org/peerreview/2016/summer/Eynon

Eynon, B., Gambino, L. M., \& Török, J. (2014). What difference can ePortfolio make? A field report from the connect to learning project. International Journal of ePortfolio, 4(1), 95114. https://www.theijep.com/pdf/IJEP127.pdf

Farrell, O. (2018). Failure to launch: The unfulfilled promise of eportfolios in Irish higher education: An opinion piece. DBS Review, 2, 154-163.

https://dbsbusinessreview.ie/index.php/journal/article/view/30/23

Farrell, O. (2019, November 13). National survey of ePortfolio practice. ePortfolio Ireland: Connect, ignite, elevate - A professional learning network for ePortfolio practitioners and researchers. https://eportfolioireland.wordpress.com/

Farrell, O. (2020). From Portafoglio to Eportfolio: The Evolution of Portfolio in Higher Education. Journal of Interactive Media in Education, 2020(1), p.19. DOI:

http://doi.org/10.5334/jime.574

Giamio-Ballard, C., \& Hyatt, L. (2012). Reflection-in-action teaching strategies used by faculty to enhance teaching and learning. Networks: An Online Journal for Teacher Research, 14(2), 3, n.p.. https://doi.org/10.4148/2470-6353.1073

Green, J., Wyllie, A., \& Jackson, D. (2014). Electronic portfolios in nursing education: A review of the literature. Nurse Education in Practice, 14(1), 4-8. https://www.nurseeducationinpractice.com/article/S1471-5953(13)00170-4/pdf 
Harring K., \& Luo, T. (2016). EPortfolios: Supporting reflection and deep learning in highimpact practices. Peer Review, 18(3), 9-12.

Hoven, D. (2020). Lifelong and life-wide learning: The transformative role of e-portfolios in online graduate education. In S. Brigham, R. McGray, \& K. Jubas (Eds.), Adult education and lifelong learning in Canada: Critical legacy (pp. 210-221). Thompson Educational Publishing.

Hoven, D. (2014). ePortfolios in post-secondary education: An alternate approach to assessment. UAE Journal of Educational Technology and eLearning, ePortfolio edition, December (5), 11-19. https://portfolio.elab.athabascau.ca/user/debra-hoven/debra-sacademic-e-portfolio

Inter/National Coalition for Electronic Portfolio Research. (2003). INCEPR website. http://incepr.org/

King, A. (1993). From sage on the stage to guide on the side. College Teaching, (41)1, 30-35. https://faculty.washington.edu/kate1/ewExternalFiles/SageOnTheStage.pdf

Kuh, G. D. (2008). High-impact educational practices: What they are, who has access to them, and why they matter. Association of American Colleges and Universities. http://provost.tufts.edu/celt/files/High-Impact-Ed-Practices1.pdf

Marshall M., Mills A, \& Bartlett, L. (2017). ePortfolio assessment as faculty development: Gathering reliable data and increasing faculty confidence. International Journal of ePortfolio, 7(2), 187-215. https://files.eric.ed.gov/fulltext/EJ1159839.pdf

McNair, T. B., \& Albertine, S. (2012). Seeking high-quality, high-impact learning: The imperative of faculty development and curricular intentionality. Peer Review, 14(3), 4-5. https://www.proquest.com/docview/1243370539

Penny Light, T., Chen, H.L., \& Ittelson, J.C. (2012). Documenting learning with ePortfolios: A guide for college instructors. Jossey Bass.

Ravet, S. (2005). ePortfolio for a learning society. Academia.

https://www.academia.edu/1073713/ePortfolio_for_a_learning_society

Ring, G. Ramirez, B. \& Bracket, B. (2016). ePortfolios and faculty engagement: Measuring change through structured experiences. International Journal of ePortfolio, 6(1), 23-31. https://eric.ed.gov/?id=EJ1108640

Scholz, K.W., Tse, C.T., \& Lithgow, K.L. (2017). Unifying experiences: Learner and instructor approaches and reactions to ePortfolio usage in higher education. International Journal of ePortfolio, 7(2), 139-150. https://files.eric.ed.gov/fulltext/EJ1159901.pdf

Scully, D., O’Leary, M. \& Brown, M. (2018). The learning portfolio in Higher Education: A game of snakes and ladders. Dublin: Dublin City University, Centre for Assessment Research, Policy \& Practice in Education (CARPE) and National Institute for Digital Learning (NIDL). 
Tosh, D., Penny Light, T., Fleming, K., \& Haywood, J. (2005). Engagement with electronic portfolios: Challenges from the student perspective. Canadian Journal of Learning and Technology, 31(3). https://cjlt.ca/index.php/cjlt/article/view/26492

Tse, C. T., Scholz, K. W., \& Lithgow, K. (2018). Beliefs or intentionality? Instructor approaches to ePortfolio pedagogy. The Canadian. Journal for the Scholarship of Teaching and Learning, 9 (3). https://doi.org/10.5206/cjsotl-rcacea.2018.3.1

Vaughan, N., Cool, R., MacIsaac, K., \& Stogre, T. (2017). ePortfolios as over-arching high impact practice for degree programs. The AAEEBL ePortfolio Review, 1(3), 36-45. https://eportfoliogr.weebly.com/uploads/2/1/0/4/21044446/aepr_v1n3.pdf

Wade, A., Abrami, P. C., \& Sclater, J. (2005). An electronic portfolio to support learning. Canadian Journal of Learning and Technology, 31(3), 25-30.

https://files.eric.ed.gov/fulltext/EJ1073692.pdf

Watson, C. E., Kuh, G. D., Rhodes, T., Light, T. P., \& Chen, H. L. (2016). Editorial: ePortfolios - The eleventh high impact practice. International Journal of ePortfolio, 6(2), 6569. http://www.theijep.com/pdf/IJEP254.pdf

Wenger, E. (1998). Communities of practice: Learning, meaning, and identity. Cambridge University Press. https://doi.org/10.1017/CBO9780511803932

Zuba Prokopetz, R. (2020a, July 17). BL best practices: Four constructs that underpin deep learning mediated by ePortfolios. The IABL Newsletter \#5. https://drive.google.com/file/d/1TUjEoPZdSrsoDt309Xq6AekhoHRylye/view?fbclid=IwAR1n7p72FNYAzhNH3o2aZt2PfpY9ixJDB2RIMKZ3xIDpTaEc3c Zp89BxLHs

Zuba Prokopetz, R. (2020b, October 17). Electronic portfolios: Open pedagogy in spaces of the Internet [video file]. Open Education Global Conference Connecting the Global Open Education Community - Taipei. https://www.youtube.com/watch? $\mathrm{v}=2 \mathrm{tkjd} 2 \mathrm{cEF} 0 \mathrm{I} \& \mathrm{t}=18 \mathrm{~s}$

Zuba Prokopetz, R. (2013, March 14). ePortfolio research.

https://www.slideshare.net/RitaProkopetz/e-portfolio-powerpoint-presentation 